\title{
Balancing the extremes - a brief history of the Pukaki area
}

\author{
S.J. CAMERON \\ Ben Ohau Station, 527 Glen Lyon Road, Twizel 7944, New Zealand \\ benohau@xtra.co.nz
}

I have been asked as an 'old' local to present this conference with brief history of the Pukaki area. This area has always been one of extremes, scorching summers and freezing winters, but often the extremes were derived from outside decision making. You will start to understand this as I guide you through the past 161 years.

A map, printed in 1856 , shows that the area was virtually uncharted. This was the year of the first occupation of Run 45, situated at the south-east end of Lake Pukaki and was granted to Messrs. Watson, Gladstone and Francis Sinclair. The rest of the runs being occupied over the next 2 years. A map printed 34 years later shows a different story. The Commissioner's belief was that the area would likely become a large community with many sections set aside for settlement. Note also that the Mackenzie Plains ran to the Pukaki River with all the land south of this river being named the Upper Waitangi Plains.

All the settler's possessions were packed in on horse and sleds. After initial exploration of the valleys they discovered that there was an immediate need for shelter and settlers set to and built modest little crofter-style cottages and huts. Another priority was firewood and apart from the beech forest at the head of the Lake Ohau they mostly relied upon driftwood washed down the lakes for their fires, plus packed in bags of coal.

Poplars and willows were planted to provide quick shelter and wood. Over time wagons, carts and also traction engines created basic tracks, and ferries were established at the outlets of Tekapo and Pukaki rivers. Soon after, a massive flood in 1878 destroyed the Pukaki ferry and flooded Richmond House at Lake Tekapo. It is interesting to note from early records that most early human deaths in the Mackenzie were from drowning or exposure. This prompted the need for bridges and accomodation houses. The new bridges had dire consequences for the Mackenzie Country as they allowed rabbits to flow in from North Otago.

A massive snowfall in 1895 caused huge stock losses for everyone in the basin and along with the rabbit plague, it had everyone questioning the area's suitability for farming. This I believe was the primary reason that the Government instigated the release of runs in 1911. It was to become the government's first intervention on local run holders thus creating changes in existing boundaries. These were largely desk top exercises as the fence-lines were often drawn in ridiculous places that did not reflect the natural boundaries and contours. This did not, however, create any better security of tenure which was something that the leaseholders craved.

A huge effort with manpower, arsenic then strychnine poison saw the rabbit numbers back to controllable levels and by the early1900s the Government deemed the land capable of further subdivision. The 19141918 war was followed by the Government-led soldier resettlement programme. Large run holdings were pressured into relinquishing substantial areas of land so the Government could create small grazing runs. The incentive was to provide 200 acres ( 81 ha) of freehold land around the existing homestead and also provide a 33 year lease with perpetual rights of renewal. This of course was the precursor to what later became the template for the 1948 Land Act.

The 1920s were a prosperous time for wool producers and many properties moved towards mechanisation, but the 1929 share market crash and consequent depression hit New Zealand hard and the Mackenzie was no exception. In the early1930s a large gang of unemployed workers camped in tents and built the rock-walled road we now see around the northern side of Lake Ohau. This was followed by the raising of LakeTekapo then Lake Pukaki in 1947 for hydropower generation. The island featured on the old five pound note was lost forever along with the natural lake edges. After the second world war the Mackenzie experienced the greatest changes to the basin. First was the relocation of Pukaki village and hotel to the southern side of the river before the first raising of the lake with a hydro dam.

The need for New Zealand to supply England with food after the war saw the introduction of subsidies to stimulate growth. New methods were being discovered to distribute fertiliser and poisoned 1080 carrot by aircraft, access tracks were pushed in by bulldozers, 4-wheel drive Land Rovers arrived on the scene along with new haymaking equipment and new methods of pasture development. All this was supported by the Department of Scientific and Industrial Research (DSIR) with pasture establishment trials throughout the basin. This was crucial in helping everyone improve their pastures so the sheep and cattle could maintain their bodyweights throughout the 5 month winters. I can still remember as a young boy listening to the interesting debate often held around our kitchen table along with neighbours and these new characters that had arrived on 
the scene. There were professors, doctors, researchers and conservators. Names like Kevin O'Connor, Brian Molloy, Lance McCaskill and and Peter Clifford come to mind. They all left a huge impression on the locals with their lively discussions, especially after a few of my father's heavy-handed whiskeys! I believe it was a time of great learning for all concerned. Everyone joined in and we all felt we were working towards a brighter more prosperous future.

All through the 1950s tourism and recreation were rapidly becoming part of this area's diversity. This was largely due to the Mt Cook Company with their buses and ski planes, supported also by the Tourist Hotel Corporation at the Hermitage. For the first time the outside world was discovering our beautiful surroundings. New Zealanders also were becoming more affluent and mobile and were beginning to explore their country. William (Bill) Hamilton, our famous local from Irishman's Creek, invented the scraper to build his own farm hydro dam and was involved with developing the jet boat.

The 1960s was focused around the building of the new earth dam at Otematata and the raising of the new man-made Lake Benmore. Bulldozer tracks were pushed through to accommodate the huge steel transmission towers that were appearing all over our virgin landscape.

Rabbits and geese still remained as the two primary challenges for the farming community, but new development opportunities were exciting and many farms were improving their pastures by establishing clover to make their properties more sustainable through the cold winter months. It was around this time families began to see random surveyors wandering around their properties. These people were employed by the Ministry of Works and were beginning the exploratory work on the Upper Waitaki Power Project. Nobody would have believed the changes we were about to see as a consequence of this project. The Government promised farmers another incentive. This time the compensation for this huge disruption that was encountered between 1967 and 1983, was the right to take water for irrigation from the massive canals that were about to sever the land. The Government bought three properties on the southern edge of Lake Pukaki, so we felt the pressure of the imposing scheme even before it eventuated. Losing three farm families and our local Pukaki community disappearing under water was a huge adjustment for my parents and other locals. More unsettling was the arrival of the town of Twizel, where 6000 people arrived virtually overnight to construct the massive Upper Waitaki Project. It was amazing how quickly this all happened and despite the disruption, farming continued to have its normal challenges. These always included snows, floods and rabbits until a new threat started to emerge.

Trees! As part of the pastoral lease arrangements two acres $(0.81 \mathrm{ha})$ of forest were to be planted each year. In 1958, one local MAF official noticed that this was not being adhered to, so organised some financially assisted packages of Pinus contorta, Pinus nigra and Pinus sylvestris to be planted as shelter belts. Although this was done with good intention little did he know the consequences of his actions. Unfortunately, these trees had been sourced from poor quality provenance and were virtually worthless as forestry trees.

During the 1980s the Government removed all rural subsidies. This coincided with a build up of rabbits mainly due to a reduction of the toxic loading of 1080 which created neo-phobic rabbits or bait shyness and we lacked any alternative control methods. Without subsidies everyone's incomes had reduced dramatically. Fine wool then dropped to its lowest prices in years. This created a perfect storm of desertification by the rabbit and the consequential invasion of hawkweed as a symptom of the degradation in the drier areas of the basin. Without funding the Rabbit Boards were disbanded and after much deliberation we were delivered the Rabbit and Land Management Programme. The most rabbit prone properties were assisted with funding for poisoning and rabbit fencing. Landcare groups were encouraged and despite all the efforts the rabbit problem remained until the illegal introduction of Rabbit Calicivirus Disease (RCD) in 1997. Although a serious biosecurity breach this virus was successful and has kept the rabbit at low numbers for over 20 years.

The push for more conservation land in New Zealand to add to the existing five million hectares saw the advent of the Tenure Review Process.The initial Government intent was to retire another million hectares from pastoral leases into conservation. This was a voluntary process where the run holders were able to trade their perpetual rights of pasturage on identified high quality conservation land to gain the freehold of their remaining farmland. Many properties voluntarily entered into this long-winded process. Initially in this process there was no monetary value on the conservation land, but a sale of one local property by the Government using the Heritage Fund changed that forever and has seen the conservation value expand well in excess of the pastural land value thereafter, and consequently the process has gained many critics. Left with smaller properties it was reasonable to expect that farmers would need to further develop their properties to remain viable. Consequently, we have seen impressive lifts in stock performance over the last 2 decades. Most farm families have created a diversity of developed and irrigated pasture on their better soils and with their mix of oversown and topdressed extensive blocks, have 
increased the plant cover and made their properties much more sustainable and drought resistant.

Some farmers are taking advantage of the increasing tourist numbers if they happen to pass by their gates. There is concern, however, that the Mackenzie District Council's plan 13 has restricted the ability for onfarm tourist development and made it very onerous to create any diversify on-farm. In my opinion these rules will stifle farmers from being innovative as they lock everyone into status quo thinking at a time we need to be using science to help develop new technologies and options.

Now that whole farm plans are required, hopefully there will be agreater understanding by authorities of the on-farm complexities that confront each and every farming family. My concern is whether there is going to be enough flexibility in the district plan rules to enable families to take advantage of these new technologies and ideas as the dynamics change into the future. A top down attitude has now appeared for decision making processes and history should warn us that this has never worked.

I applaud, however, the recent move towards an interagency collaborative strategy to help fund the much needed infrastructure for tourism. New Zealanders' are becoming highly critical of the immediate effects that the tourist industry is having on their environment and also their ability to enjoy their annual holiday in the high-country.

We are already contaminated with overflowing public facilities, trash-lined highways, every lay-by has exposed excrement in the bushes and travelling on our secondary roads is a form of Russian roulette. I believe our once friendly Kiwi demeanour towards overseas tourists is fast becoming replaced with resentment. If the Mackenzie is to retain its uniqueness and desirability as a destination it will require huge investment in infrastructure which includes our national roading network. Hopefully, our local bodies and agencies will be financially assisted to create this much needed infrastructure and the Government needs to heed the communities pleas and act quickly. This is urgent for they are now predicting tourist numbers to double in New Zealand by 2025.

In conclusion, I leave you with two questions. We have witnessed a large increase in the size of the conservation estate in the Mackenzie through the tenure review process on land that originally had both conservation and pastoral values. In my opinion, the build up of senesced herbage is smothering the small inter-tussock species and creating a large fuel loading for fire. Once clean grasslands are reverting in some cases into dense scrubland.

Is anyone investigating the science behind this dynamic change? It is after all a large area and if we have the wrong management then we could be creating a difficult legacy for future generations. I believe we now have the potential for a large devastating fire event in the summer when all the plants are most vulnerable. The high-country family has managed to endure the climatic extremes, the outside meddling, and etched out a diverse existence in this environment for 160 years. In general, I believe there has been a history of good stewardship of these lands, but will future families be able to sustainably farm this area for another 100 years? The management of conservation lands and productive grasslands has become more difficult and this requires the best science available.

Simon Cameron is a fourth generation farmer near Twizel. His family has been farming Ben Ohau Station since 1891. The different generations have experienced and documented the vast changes that have occurred during their 127 years of occupation. 
